\title{
Sistem Monitoring Kesehatan Dalam Penentuan Kondisi Tubuh Dengan Metode Fuzzy Mamdani
}

\author{
Sanyyah Plowerita \\ Jurusan Teknik Elektro \\ Program Studi Teknik Telekomunikasi, \\ Politeknik Negeri Sriwijaya Palembang, \\ sanyyahplowerita@yahoo.com \\ Irawan Hadi \\ Jurusan Teknik Elektro \\ ProgramStudi Teknik Telekomunikasi, \\ Politeknik Negeri Sriwijaya Palembang, \\ irawanhadi657@yahoo.com
}

\author{
Ade Silvia Handayani \\ Jurusan Teknik Elektro \\ Program Studi Teknik Telekomunikasi, \\ Politeknik Negeri Sriwijaya Palembang, \\ ade_silvia@polsri.ac.id \\ Nyayu Latifah Husni \\ Jurusan Teknik Elektro \\ ProgramStudi Teknik Elektronika, \\ Politeknik Negeri Sriwijaya Palembang, \\ nyayu_latifah@polsri.ac.id
}

\begin{abstract}
In this study, designing a health monitoring system with an Android-based Application of Health Detector (AHD) application. The data displayed is an input for multi-sensor readings from the detection of body health. From the detected health, it will provide a determination of the body's health condition, using the fuzzy mandani algorithm. The variables calculated were age, gender, heart rate, body temperature, systolic blood pressure, diastolic blood pressure, and blood oxygen levels. The stages of the fuzzy mamdani method in determining body health conditions include the formation of fuzzy sets, application of implications functions, and composition of rules. From the results of this study, it was found that the age factor affects health conditions. Older people tend to have indications of health conditions, only some of them have indicated health conditions, and almost all of them have healthy health conditions. The level of accuracy of the fuzzy mamdani method in this study was $\mathbf{8 5 . 1 8 \%}$. This is because in this study many variables are used which causes many rules to be made so that they are prone to errors.
\end{abstract}

Keywords- Algorithm, Body Health, Fuzzy Mamdani, and Health Detection

\section{PENDAHULUAN}

Berdasarkan informasi dari website resmi WHO (World Health Organization) sudah lebih dari 195 juta kasus Covid-19 diseluruh dunia. Dengan jumlah kasus yang besar ini, salah satu hambatan dalam memantau kondisi kesehatan ialah kurangnya tenaga medis dan peralatan kesehatan. Oleh karena itu, diperlukan alat pemantauan kesehatan jarak jauh, untuk mengetahui kondisi kesehatan secara real-time.

Perancangan alat pemantauan kesehatan telah dilakukan oleh beberapa peneliti, seperti penelitian Ridho Surya Kusuma dkk [1] dan Ammar Sana' Ramadhan [2] alat pemantauan kesehatan dirancang untuk memantau kesehatan jantung berbasis IoT. Pada penelitian Najeed Ahmed Khan dkk [3] pemantauan kesehatan dirancang untuk memantau tanda vital tubuh manusia secara real-time menggunakan Bluetooth dan WLAN. Teknologi Wireless Local Area Network (WLAN) yang digunakan yaitu Wireless Body Area Network (WBAN).

Wireless Body Area Network (WBAN) merupakan teknologi jaringan sensor nirkabel yang dipasang pada bagian tubuh manusia. Arsitektur WBAN dalam pemantauan kesehatan terdiri dari nodes, chip mikrokontoller, modul komunikasi nirkabel, dan perangkat komunikasi data yang terhubung pada jaringan tertentu [4]. Nodes ini berukuran kecil, lebih hemat biaya, nyaman, dan ringan. Namun WBAN memiliki sumber energi yang terbatas, sehingga perlunya mengelola energi yang tersedia secara hati - hati dan efisien [5] Dengan keterbatasan WBAN ini penggunaan nodes yang menjadi parameter kesehatan lebih sedkit.

WBAN harus mampu dalam mengatasi keterbatasan tersebut untuk menyediakan pemantauan yang handal. Seperti penelitian M. Udin Harun dkk [6] WBAN diimplementasikan untuk pemantauan kesehatan dengan parameter pemantauan diataranya suhu tubuh, denyut jantung, dan kadar oksigen dalam darah dengan pengunaan Zigbee sebagai media transmisi, sehingga konsumsi daya rendah. Kemudian, inovasi dalam pemantaun kesehatan serupa dilakukan [7] dengan parameter pemantauan seperti suhu tubuh, EKG, detak jantung, oksigen dalam darah, aliran udara dan posisi tubuh.

Dengan banyaknya parameter pemantauan yang digunakan seperti penelitian [6] [7] maka, informasi kesehatan yang didapat juga lebih banyak. Tidak hanya terfokus pada satu parameter seperti penelitian [1] [2]. Pemantauan kesehatan dengan penggunaan parameter yang lebih banyak, semakin meningkatkan kualitas sistem pemantauan tersebut. Namun agar lebih efektif lagi perlunya ditarik sebuah kesimpulan dari hasil pemantauan kesehatan untuk menentukan kondisi kesehatan pasien.

Dalam menentukan kondisi kesehatan tubuh memerlukan bantuan dari Artificial Intelligence (AI), seperti fuzzy logic [8], neural network [9], dan decision tree [10]. Dari ketiga Artificial Intelligence (AI) tersebut, fuzzy mamdani merupakan salah satu 
metode dari fuzzy logic yang sering digunakan dalam penarikan kesimpulan. Pada prosesnya menggunakan kaidah linguistik yang dapat dianalis secara matematis, sehingga lebih mudah dipahami. Kelebihan lainnya dari fuzzy mamdani lebih memperhatikan kondisi yang akan terjadi dari setiap daerah fuzzynya, sehingga hasil keputusan lebih akurat [11], dibuktikan pada penelitian [12] akurasi mamdani diatas $80 \%$.

Dari latar belakang yang telah dipaparkan, perlunya sistem pemantauan kesehatan menggunakan teknologi WBAN yang memanfaatkan fuzzy mamdani untuk menentukan kondisi kesehatan. Sistem pemantauan kesehatan ini diharapkan dapat membantu tenaga medis dalam memantau kesehatan pasien tanpa adanya kontak fisik yang terjalin. Kondisi kesehatan yang didapatkan dari hasil pemantauan terbagi menjadi tiga parameter yaitu Sehat, Indikasi, dan Butuh Tindakan.

\section{TEORI DASAR}

Logika fuzzy adalah suatu cara yang digunakan untuk menggambarkan ruang masukan ke dalam ruang keluaran yang mempunyai nilai kontiyu. Kelebihan dari teori logika fuzzy adalah kemampuan dalam proses penalaran secara bahasa (linguistic reasoning), misalkan besaran kecepatan laju kendaraan yang diekspresikan dengan pelan, agak cepat, cepat, dan sangat cepat [13]. Fuzzy Inference System merupakan sebuah kerangka kerja perhitungan berdasarkan konsep teori himpunan fuzzy dan pemikiran fuzzy yang digunakan dalam penarikan kesimpulan atau suatu keputusan [14]. Logika fuzzy dapat dikatakan perluasan dari logika multi nilai yang tujuannya adalah dugaan pemikiran daripada solusi yang tepat [15].

Pada penelitian Slamet Widodo dkk [15] fuzzy logic diimplementasikan pada sistem detector gas beracun berbasis mikrokontroller, Gas - gas beracun yang dideteksi antara lain $\mathrm{SO}_{2}, \mathrm{CO}_{2}$, dan $\mathrm{CH}_{4}$. Dari gas - gas berbahaya ini dikelompokkan ke dalam himpunan fuzzy normal, agak tebal, terkonsentrasi dan sangat pekat. Hasil yang diharapkan pada penelitian ini adalah pada suatu ruangan tertutup yang terpapar gas - gas itu, apakah aman atau berbahaya bagi aktivitas manusia. Namun tiga parameter gas berbahaya saja kurang efektif untuk mendapatkan keputusan suatu ruangan tersebut dalam kondisi aman atau berbahaya, beda halnya dengan penelitian Anisa dkk [12] fuzzy logic digunakan dalam pengambilan keputusan prakiraan cuaca. Dalam penelitian ini menggunakan dua metode yaitu sugeno dan mamdani. Metode sugeno dalam memperkirakan cuaca hanya menggunakan tiga parameter. Dan hasil prakiraan cuaca yang didapat hanya diatas $60 \%$. Sedangkan metode mamdani menggunakan lima parameter untuk memprakirakan cuaca, dengan parameter yang cukup banyak ini perhitungan yang dilakukan cukup rumit. Namun dengan penggunaan parameter yang banyak, mamdani berhasil memperkirakan cuaca dengan akurasi diatas $80 \%$.
Berdasarkan penelitian - penelitian yang menggunakan fuzz y logic seperti diatas, terlihat fuzzy mamdani lebih kompeten untuk memberikan keputusan atau simpulan dengan penggunaan parameter yang lebih banyak. Pada penelitian ini akan digunakan fuzzy logic yaitu metode fuzzy mamdani untuk menentukan

kondisi kesehatan tubuh. Hal ini bertujuan untuk mendapatkan hasil performansi akurasi yang tinggi, sehingga penentuan kondisi kesehatan melalui sistem monitoring kesehatan dapat dipergunakan oleh tenaga medis.

\section{A. Pendekatan Algoritma Fuzzy Logic}

Fuzzy Logic adalah salah satu bidang Artificial Intelligent (AI). Artificial Intelligent merupakan ilmu komputer yang memperlajari mesin (komputer) dapat bertindak seperti layaknya manusia bahkan lebih baik [16]. Fuzzy logic merupakan cara untuk mencari solusi dari permasasalan yang dianggap tidak jelas [17]. Dalam penyelesaiannya, fuzzy logic menggunakan linguistic seperti dalam menjelaskan kecepatan detak jantung yaitu lemah, normal dan cepat.

Adapuun fuzzy logic memiliki empat tahapan dalam penaksiran kesimpulan, yaitu:

1. Fuzzifikasi

Variabel input diubag ke dalam bentuk variabel fuzzy menggunakan fungsi keanggotaan.

2. Inferensi

Variabel input diproses dengan aturan - aturan (rules) yang telah ditentukan.

3. Komposisi

Variabel output dari semua aturan akan digabungkan menjadi himpunan fuzzy baru.

4. Defuzzifikasi

Variabel output dari himpunan fuzzy akan dikonversikan Kembali ke dalam bentuk bilangan dengan menggunakan fungsi keanggotaan telah digunakan sebelumnya.

\section{B. Fuzzy Mamdani Sebagai Algoritma \\ Pengambilan Keputusan}

Algoritma logika fuzzy menjadi salah satu algoritma yang sering digunakan pada penelitian yang berkaitan dengan pengambilan keputusan. Dalam menentukan keputusan metode fuzzy mamdani terdapat dua proses penting yaitu fuzzifikasi dan defuzzifikasi. Proses tersebut untuk menentukan perubahan masukkan dari bentuk tegas menjadi fuzzy (variabel linguistik) dan menentukan nilai penegasan, pada metode mamdani dengan menggunakan metode centroid (Composite Moment) [18].

Pada penelitian S.Nurmuslimah [18] fuzzy mamdani dapat mengambil keputusan status kesehatan anak dengan umur dibawah lima tahun serta dapat memberikan solusi kebutuhan kalori atau energi. Sejalan juga dengan penelitian yang dilakukan oleh Munjiat Setiani Asih [19] fuzzy mamdani dapat mengambil keputusan untuk tanaman disiram atau tidak. Dari hasil pengujian yang dilakukan dapat disimpulkan bahwa fuzzy sudah diterapkan dengan 
baik, hal ini terlihat dari hasil pengujian dimana saat suhu udara 30 derajat celcius dan kelembaban tanah $50 \%$ maka tanah tersebut tidak akan disiram. Hal ini didapatkan dari pengetahuan yang diterapkan ke dalam mikrokontroler.

Dari penelitian yang sudah djelaskan dapat dikatakan metode fuzzy mamdani memiliki algoritma yang baik sebagai sistem pengambilan keputusan.

\section{METODE PENELITIAN}

Tahapan metode penelitian adalah tahapan tahapan yang digunakan dalam pelaksanaan penelitian yang dibuat dalam bentuk blok diagram secara keseluruhan. Adapun dalam penelitian ini terdapat dua tahapan diantaranya tahapan perancangan perangkat keras dan tahapan perancangan perangkat lunak berupa perancangan aplikasi deteksi kesehatan berbasis android yang didalamnya dimasukkan metode fuzzy mamdani sebagai penentu kondisi kesehatan.

\section{A. Perancangan Perangkat Keras}

Pada perancangan perangkat keras mencakup pemilihan komponen yang digunakan dan membuat rangkaian desain skematik yang digambarkan melalui blok diagram, sehingga dapat dibuat suatu sistem yang sesuai yang diharapkan. Gambar 1 adalah blok diagram untuk perancangan perangkat keras.

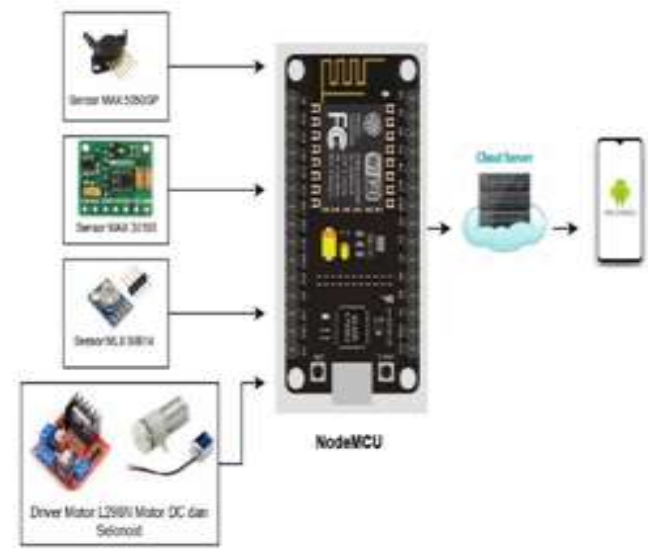

\section{Gambar 1. Blok Diagram Perangkat Keras}

Pada gambar 1, sistem monitoring kesehatan dirancang menggunakan mikrokontroller NodeMCU yang dilengkapi dengan modul ESP 8266 dan dilengkapi dengan sensor - sensor seperti yang ada pada gambar. Setelah mendapatkan data pembacaan sensor, NodeMCU yang telah terhubung dengan wifi akan mengirimkan hasil pembacaan sensor ke database dan dikirim secara real-time. Kemudian, android akan menampilkan hasil pembacaan data sensor.

\section{B. Perancangan Perangkat Lunak}

Perancangan perangkat lunak sangat penting untuk pemprosesan matematis seluruh program. Inti dari perancangan perangkat lunak ini ialah memasukkan metode fuzzy mamdani sebagai penentuan kondisi kesehatan tubuh. Perancangan perangkat lunak pada sistem ini merancang sebuah aplikasi Aplication Of Health Detector (AHD) berbasis android. Pada aplikasi ini dimasukkan metode fuzzy mamdani sebagai penentu kondisi kesehatan, berdasarkan tiga parameter yaitu Sehat, Indikasi, dan Butuh Tindakan. Gambar 2 adalah flowchart perancangan perangkat lunak dari penentuan kondisi kesehatan dengan metode fuzzy mamdani.

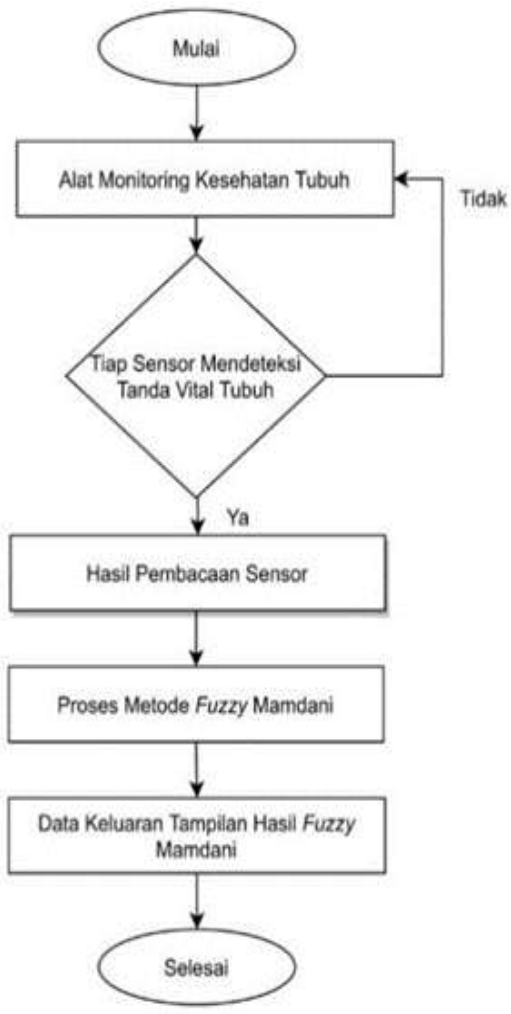

Gambar 2. Flowchart Perangkat Lunak

\section{Pengolahan Data}

Setelah melalui tahapan perancangan perangkat keras dan perangkat lunak, maka selanjutnya adalah proses pengolahan data. Pengaplikasian metode fuzzy mamdani untuk pengolahan data pada sistem ini ialah dimulai dari input dan output. Pada input terdapat tujuh masukan yang terdiri dari usia, jenis kelamin, hasil pembacaan suhu tubuh, tekanan darah sistolik dan diastolik, detak jantung, dan kadar oksigen dalam darah. Kemudian menghasilkan tiga ouput berupa kondisi kesehatan. Setelah sensor telah mendeteksi dan mengirimkan kepada android, maka akan didapatkan informasi berupa hasil data pemantauan kesehatan tubuh dimana data tersebut diolah terlebih dahulu sebelum dilakukan penentuan. Pengolahan data inilah yang dilakukan oleh metode fuzzy mamdani, dimana fuzzy mamdani ini terdapat di android. Gambar 3 merupakan tahapan pengolahan data dengan metode fuzzy mamdani. 


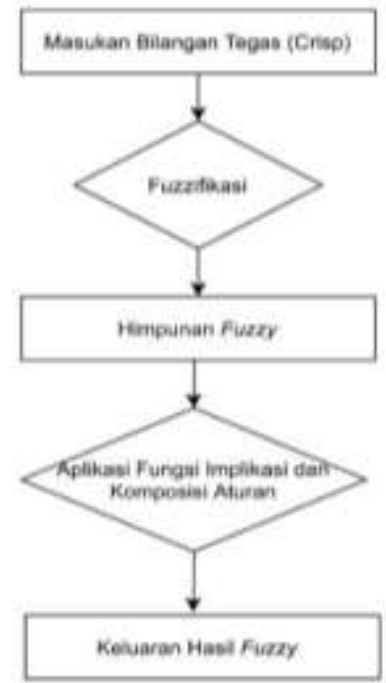

Gambar 3. Flowchart Proses Metode Fuzzy Mamdani

Untuk mendapatkan output yaitu penentuan kondisi kesehatan tubuh diperlukan tiga tahapan yaitu pembentukan Himpunan Fuzzy atau dikenal dengan Fuzzifikasi.

Tabel 4. Semesta Pembicaraan

\begin{tabular}{|c|c|}
\hline Variabel Fuzzy & Semesta Pembicaraan \\
\hline Usia & {$[12,90]$} \\
\hline Jenis Kelamin & {$[0,1]$} \\
\hline Detak Jantung & {$[0,120]$} \\
\hline Suhu Tubuh & {$[0,40]$} \\
\hline Tekanan Darah Sistolik & {$[0,160]$} \\
\hline Tekanan Darah Diastolik & {$[0,100]$} \\
\hline Kadar Oksigen $\left(\mathrm{SpO}_{2}\right)$ & {$[0,100]$} \\
\hline
\end{tabular}

Tabel 5. Tabel Himpunan Fuzzy

\begin{tabular}{|c|c|c|c|}
\hline $\begin{array}{c}\text { Variabel } \\
\text { Fuzzy }\end{array}$ & $\begin{array}{c}\text { Himpunan } \\
\text { Fuzzy }\end{array}$ & Domain & $\begin{array}{c}\text { Fungsi } \\
\text { Keanggotaan }\end{array}$ \\
\hline \multirow{3}{*}{$\begin{array}{c}\text { Usia } \\
\text { (Tahun) }\end{array}$} & Muda & {$[12,21]$} & Linear Turun \\
\hline & Sedang & {$[18,71]$} & Trapesium \\
\hline & Tua & {$[68,90]$} & Linear Naik \\
\hline \multirow{2}{*}{$\begin{array}{c}\text { Jenis } \\
\text { Kelamin }\end{array}$} & Laki - laki & {$[0,1]$} & Segitiga \\
\hline & Perempuan & {$[0,1]$} & Linear Naik \\
\hline \multirow{3}{*}{$\begin{array}{c}\text { Detak } \\
\text { Jantung } \\
\text { (bpm) }\end{array}$} & Lemah & {$[0,72.5]$} & Linear Turun \\
\hline & Normal & {$[50,95]$} & Segitiga \\
\hline & & $\begin{array}{r}72.5, \\
120]\end{array}$ & Linear Naik \\
\hline \multirow{3}{*}{$\begin{array}{l}\text { Suhu } \\
\text { Tubuh } \\
\left({ }^{\circ} \mathrm{C}\right)\end{array}$} & lin & {$[0,36]$} & Linear Turun \\
\hline & Normal & {$[35,37.5]$} & Trapesium \\
\hline & Panas & {$[37,40]$} & Linear Naik \\
\hline \multirow{4}{*}{$\begin{array}{l}\text { Tekanan } \\
\text { Darah } \\
\text { Sistolik } \\
(\mathrm{mmHg})\end{array}$} & Rendah & {$[0,110]$} & Linear Turun \\
\hline & Normal & {$[107,123]$} & Trapesium \\
\hline & Agak Tingg & {$[120,143]$} & Trapesium \\
\hline & Tinggi & {$[140,160]$} & Linear Naik \\
\hline \multirow{4}{*}{$\begin{array}{l}\text { Tekanan } \\
\text { Darah } \\
\text { Diastolik } \\
(\mathrm{mmHg})\end{array}$} & Rendah & {$[0,60]$} & Linear Turun \\
\hline & Normal & {$[57,73]$} & Trapesium \\
\hline & Agak Tinggi & {$[70,93]$} & Trapesium \\
\hline & Tinggi & {$[90,100]$} & Linear Naik \\
\hline \multirow{2}{*}{$\begin{array}{c}\text { Kadar } \\
\text { Oksigen } \\
(\%)\end{array}$} & Rendah & {$[0,96]$} & Linear Turun \\
\hline & Normal & {$[93,100]$} & Linear Naik \\
\hline
\end{tabular}

Himpunan Fuzzy beserta fungsi keanggotaan dari variabel usia, detak jantung, suhu tubuh, tekanan darah sistolik dan kadar oksigen dalam darah direpresentasikan sebagai berikut:

a. Himpunan Fuzzy Variabel Usia

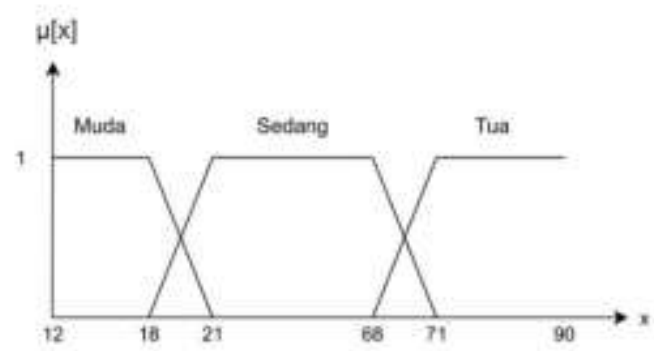

Gambar 4. Himpunan Fuzzy Usia

$$
\begin{gathered}
\mu_{\text {muda }}[x]=\left\{\begin{array}{cc}
1 ; 12 \leq x \leq 18 \\
\frac{(21-x)}{(21-18)} ; & 18 \leq x \leq 21 \\
0 ; & x \geq 21
\end{array}\right. \\
\mu_{\text {sedang }}[x]= \begin{cases}0 ; 12 \leq x \leq 18 \text { atau } x \geq 71 \\
\frac{(x-18)}{(21-18)} ; & 18 \leq x \leq 21 \\
1 ; & 21 \leq x \leq 68 \\
\frac{(71-x)}{(71-68)} ; & 68 \leq x \leq 71\end{cases} \\
\mu_{\text {tua }}[x]=\left\{\begin{array}{cc}
0 ; 12 \leq x \leq 68 \\
\frac{(x-68)}{(71-68)} ; & 68 \leq x \leq 71 \\
1 ; & x \geq 71
\end{array}\right.
\end{gathered}
$$

b. Himpunan Fuzzy Variabel Jenis Kelamin

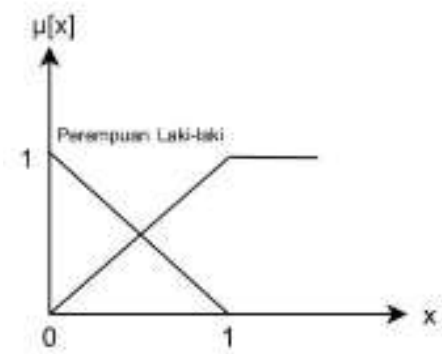

Gambar 5. Himpunan Fuzzy Jenis Kelamin

$$
\begin{aligned}
& \mu_{\text {perempuan }}[x]= \begin{cases}\frac{(1-x)}{(1-0)} ; & 0 \leq x \leq 1\end{cases} \\
& \mu_{\text {laki-laki }}[x]= \begin{cases}\left(\frac{(-0)}{(1-0)} ;\right. & 0 \leq x \leq 1\end{cases}
\end{aligned}
$$

c. Himpunan Fuzzy Variabel Detak Jantung

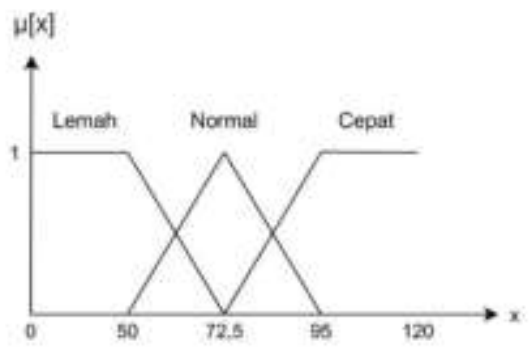

Gambar 6. Himpunan Fuzzy Detak Jantung 


$$
\begin{gathered}
\mu_{\text {lemah }}[x]=\left\{\begin{array}{cc}
1 ; & x \leq 50 \\
\frac{(72,5-x)}{(72,5-50)} ; & 50 \leq x \leq 72,5 \\
0 ; & x \geq 72,5
\end{array}\right. \\
\mu_{\text {normal }}[x]=\left\{\begin{array}{cc}
0 ; \quad x \leq 50 \text { atau } x \geq 95 \\
\frac{(x-50)}{(72,5-50)} ; & 50 \leq x \leq 72,5 \\
\frac{(95-x)}{(95-72,5)} ; & 72,5 \leq x \leq 95
\end{array}\right. \\
\mu_{\text {cepat }}[x]=\left\{\begin{array}{cc}
\frac{(x-72,5)}{(95-72,5)} ; & 72,5 \leq x \leq 95 \\
1 ; & x \geq 95
\end{array}\right.
\end{gathered}
$$

d. Himpunan Fuzzy Variabel Suhu Tubuh

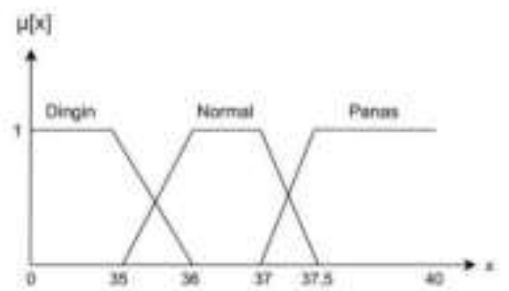

Gambar 7. Himpunan Fuzzy Suhu Tubuh

$$
\begin{gathered}
\mu_{\text {dingin }}[x]=\left\{\begin{array}{cl}
1 ; & x \leq 35 \\
\frac{(36-x)}{(36-35)} ; & 35 \leq x \leq 36 \\
0 ; & x \geq 36
\end{array}\right. \\
\mu_{\text {normal }}[x]=\left\{\begin{array}{cl}
0 ; \quad x \leq 35 \text { atau } x \geq 37,5 \\
\frac{(x-35)}{(36-35)} ; & 35 \leq x \leq 36 \\
1 ; & 36 \leq x \leq 37 \\
\frac{(37,5-x)}{(37,5-37)} ; & 37 \leq x \leq 37,5
\end{array}\right. \\
\mu_{\text {panas }}[x]=\left\{\begin{array}{cl}
0 ; & x \leq 37 \\
\frac{(x-37)}{(37,5-37)} ; & 37 \leq x \leq 37,5 \\
1 ; & x \geq 37,5
\end{array}\right.
\end{gathered}
$$

e. Himpunan Fuzzy Tekanan Darah Sistolik

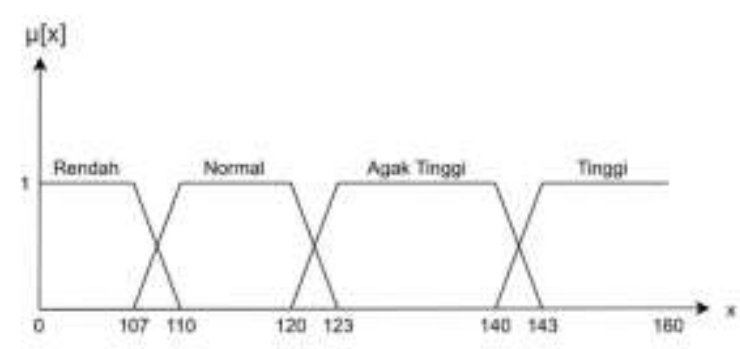

Gambar 8. Himpunan Fuzzy Tekanan Darah Sistolik

$$
\begin{aligned}
& \mu_{\text {rendah }}[x]=\left\{\begin{array}{cc}
1 ; & x \leq 107 \\
\frac{(110-x)}{(110-107)} ; & 107 \leq x \leq 110 \\
0 ; & x \geq 110
\end{array}\right. \\
& \mu_{\text {normal }}[x]=\left\{\begin{array}{cc}
0 ; \quad x \leq 107 & \text { atau } x \geq 123 \\
\frac{(x-107)}{(110-107)} ; & 107 \leq x \leq 110 \\
1 ; & 110 \leq x \leq 120 \\
\frac{(123-x)}{(123-120)} ; & 120 \leq x \leq 123
\end{array}\right.
\end{aligned}
$$

$$
\begin{gathered}
\mu_{\text {agaktinggi }}[x]=\left\{\begin{array}{cc}
0 ; \quad x \leq 120 \text { atau } x \geq 143 \\
\frac{(x-120)}{(123-120)} ; & 120 \leq x \leq 123 \\
1 ; & 123 \leq x \leq 140 \\
\frac{(143-x)}{(143-140)} ; & 140 \leq x \leq 143
\end{array}\right. \\
\mu_{\text {tinggi }}[x]=\left\{\begin{array}{cc}
0 ; & x \leq 140 \\
\frac{(x-140)}{(143-140)} ; & 140 \leq x \leq 143 \\
1 ; & x \geq 143
\end{array}\right.
\end{gathered}
$$

f. Himpunan Fuzzy Tekanan Darah Diastolik

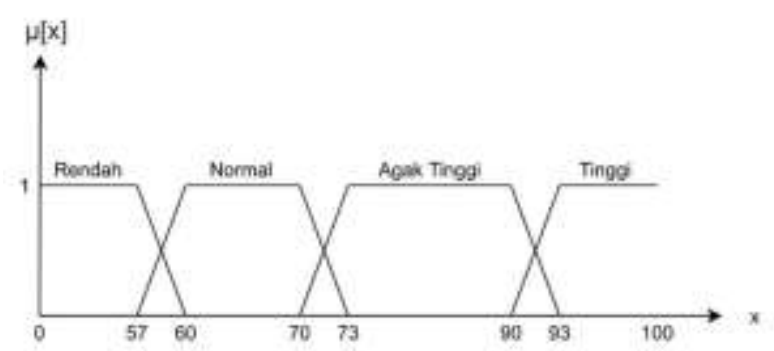

Gambar 9. Himpunan Fuzzy Tekanan Darah Diastolik

$$
\begin{aligned}
& \mu_{\text {rendah }}[x]=\left\{\begin{array}{cc}
1 ; & x \leq 57 \\
\frac{(60-x)}{(60-57)} ; & 57 \leq x \leq 60 \\
0 ; & x \geq 60
\end{array}\right. \\
& \mu_{\text {normal }}[x]= \begin{cases}0 ; & x \leq 57 \text { atau } x \geq 73 \\
\frac{(x-57)}{(60-57)} ; & 57 \leq x \leq 60 \\
1 ; & 60 \leq x \leq 70 \\
\frac{(73-x)}{(73-70)} ; & 70 \leq x \leq 73\end{cases} \\
& \mu_{\text {agaktinggi }}[x]=\left\{\begin{array}{lr}
0 ; \quad x \leq 70 \text { atau } x \geq 93 \\
\frac{(x-70)}{(73-70)} ; & 70 \leq x \leq 73 \\
1 ; & 73 \leq x \leq 90 \\
\frac{(93-x)}{(93-90)} ; & 90 \leq x \leq 93
\end{array}\right. \\
& \mu_{\text {tinggi }}[x]=\left\{\begin{array}{cc}
0 ; & x \leq 90 \\
\frac{(x-90)}{(93-90)} ; & 90 \leq x \leq 93 \\
1 ; & x \geq 93
\end{array}\right.
\end{aligned}
$$

g. Himpunan Fuzzy Kadar Oksigen $\left(\mathrm{SpO}_{2}\right)$

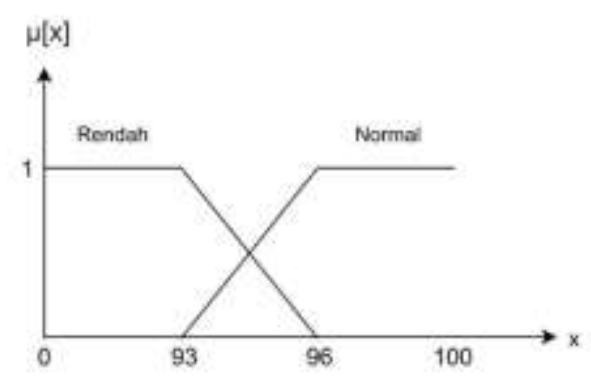

Gambar 10.Himpunan Fuzzy Kadar Oksigen

$\mu_{\text {rendah }}[x]=\left\{\begin{array}{lr}1 ; & x \leq 93 \\ \frac{(96-x)}{(96-93)} ; & 93 \leq x \leq 96 \\ 0 ; & x \geq 96\end{array}\right.$ 


$$
\mu_{\text {normal }}[x]=\left\{\begin{array}{cc}
0 ; & x \leq 93 \\
\frac{(x-93)}{(96-93)} ; & 93 \leq x \leq 96 \\
1 ; & x \geq 96
\end{array}\right.
$$

b. Aplikasi Fungsi Implikasi

Berdasarkan variabel input yang digunakan, maka dapat dibentuk aturan - aturan sebagai berikut yang terdiri dari 1728 aturan:

[Aturan 1]: Jika umur muda, jenis kelamin laki - laki, detak jantung lemah, suhu tubuh dingin, tekanan darah sistolik rendah, tekanan darah diastolik rendah, dan kadar oksigen rendah, maka status kondisi kesehatan tubuh butuh tindakan. [Aturan 1728]: Jika umur tua, jenis kelamin perempuan, detak jantung cepat, suhu tubuh panas, tekanan darah sistolik tinggi, tekanan darah diastolik tinggi, dan kadar oksigen normal maka status kondisi kesehatan butuh tindakan.

Setelah dibuatnya aturan, tahap selanjutnya ialah menentukan nilai keanggotaan dengan memakai fungsi implikasi Min yang didasari pada aturan fuzzy yang sudah dibuat.

$$
\begin{aligned}
& \propto-\text { predikat }_{i}=\mu_{A_{1}}\left[x_{1}\right] \cap \mu_{A_{2}}\left[x_{2}\right] \\
& \cap \mu_{A_{3}}\left[x_{3}\right] \cap \mu_{A_{4}}\left[x_{4}\right] \\
& \cap \mu_{A_{5}}\left[x_{5}\right] \cap \mu_{A_{6}}\left[x_{6}\right] \\
& \cap \mu_{A_{7}}\left[x_{7}\right] \\
& =\min \left(\mu_{A_{1}}\left[x_{1}\right], \mu_{A_{2}}\left[x_{2}\right], \mu_{A_{3}}\left[x_{3}\right]\right. \text {, } \\
& \left.\mu_{A_{4}}\left[x_{4}\right], \mu_{A_{5}}\left[x_{5}\right], \mu_{A_{6}}\left[x_{6}\right], \mu_{A_{7}}\left[x_{7}\right]\right) \\
& \text { dimana, i adalah aturan fuzzy ke - i. }
\end{aligned}
$$

\section{Keterangan:}

$\propto-$ predikat : Nilai minimum dari himpunan fuzzy usia, jenis kelamin, detak jantung, tekanan darah sistolik, tekanan darah diastolik, dan kadar oksigen pada aturan ke-i

$\mu_{A_{1}}\left[x_{1}\right]$ sampai $\mu_{A_{7}}\left[x_{7}\right]$ : Fungsi keanggotaan atau derajat keanggotaan usia, jenis kelamin, detak jantung, tekanan darah sistolik, tekanan darah diastolik, dan kadar oksigen pada aturan ke-i

\section{c. Komposisi Aturan}

Tahap ketiga pada metode fuzzy yaitu komposisi aturan. Mengambil nilai maksimum dari output aturan merupakan cara yang dapat digunakan untuk memperoleh solusi himpunan fuzzy.

$$
\mu_{s f}(x)=\max
$$

(min_sehat, $\max \left(\min \_\right.$indikasi, min_butuh tindakan))

Dengan $\mu_{s f}(x)$ menyatakakan hasil himpunan fuzzy yaitu kondisi kesehatan tubuh, min_sehat menyatakan nilai minimum sehat yang didapatkan dari output aturan, min_indikasi menyatakan nilai minimum indikasi dan min_butuh tindakan yang menyatakan nilai minimum butuh tindakan yang didapatkan dari output aturan.

\section{HASIL DAN PEMBAHASAN}

Pada penelitian ini menggunakan tiga alat yang digunakan untuk rentang usia yang berbeda. Adapun rentang - rentang usia yang berbeda - beda agar mengetahui kondisi kesehatan tubuh pada setiap usianya. Gambar 11 adalah hasil desain perancangan perangkat keras untuk sistem monitoring kesehatan tubuh dan hasil perancangan perangkat lunak yaitu halaman penentuan kondisi kesehatan tubuh pada aplikasi android.

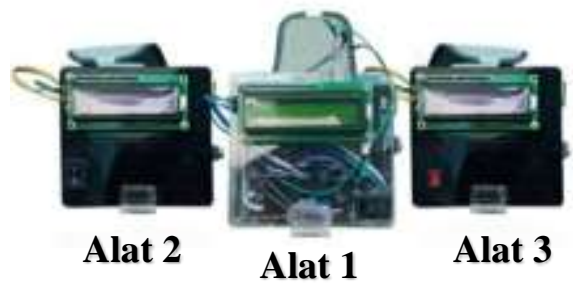

(a)

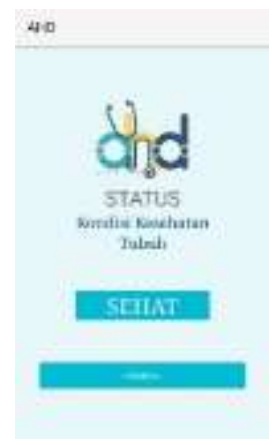

(b)

\begin{tabular}{|c|c|c|c|c|}
\hline No & $\begin{array}{c}\text { Paramater } \\
\text { Kesehatan } \\
\text { Tubuh }\end{array}$ & $\begin{array}{c}\text { Pembacaan } \\
\text { Sensor }\end{array}$ & $\begin{array}{c}\text { Kondisi } \\
\text { Kesehatan }\end{array}$ & Waktu \\
\hline \multirow{7}{*}{1.} & Usia & 60 & \multirow{7}{*}{ Sehat } & \multirow{7}{*}{$\begin{array}{c}\text { Senin, } \\
21-6- \\
2021\end{array}$} \\
\hline & Jenis Kelamin & Perempuan & & \\
\hline & Detak Jantung & 74.32 & & \\
\hline & Suhu Tubuh & 36.53 & & \\
\hline & TD Sistolik & 128.25 & & \\
\hline & TD Diastolik & 70.79 & & \\
\hline & Kadar Oksigen & 95.00 & & \\
\hline \multirow{7}{*}{2.} & Usia & 76 & \multirow{7}{*}{ Indikasi } & \multirow{7}{*}{$\begin{array}{c}\text { Senin, } \\
21-6- \\
2021\end{array}$} \\
\hline & Jenis Kelamin & Perempuan & & \\
\hline & Detak Jantung & 55.84 & & \\
\hline & Suhu Tubuh & 36.52 & & \\
\hline & TD Sistolik & 137.24 & & \\
\hline & TD Diastolik & 96.59 & & \\
\hline & Kadar Oksigen & 96.00 & & \\
\hline
\end{tabular}

Gambar 11. (a) Hasil Perancangan Perangkat Keras, (b) Hasil Perancangan Perangkat Lunak.

\section{A. Hasil Pengujian Monitoring Kesehatan Tubuh pada Alat 1}

Lokasi pengujian pada alat 1 dilakukan pada posyandu yang merupakan posyandu untuk balita, bindu, lansia, dan ibu hamil.

Tabel 6. Hasil Monitoring Kesehatan Lansia Pagi 


\begin{tabular}{|c|c|c|c|c|}
\hline \multirow{7}{*}{3.} & Usia & 63 & \multirow{7}{*}{ Indikasi } & \multirow{4}{*}{$\begin{array}{c}\text { Senin, } \\
21-6- \\
2021\end{array}$} \\
\hline & Jenis Kelamin & Perempuan & & \\
\hline & Detak Jantung & 61.00 & & \\
\hline & Suhu Tubuh & 36.60 & & \\
\hline & TD Sistolik & 120.05 & & \multirow{3}{*}{ 09:55 } \\
\hline & TD Diastolik & 75.57 & & \\
\hline & Kadar Oksigen & 95.00 & & \\
\hline
\end{tabular}

Tabel 7. Hasil Monitoring Kesehatan Lansia Siang

\begin{tabular}{|c|c|c|c|c|}
\hline No & $\begin{array}{c}\text { Paramater } \\
\text { Kesehatan } \\
\text { Tubuh }\end{array}$ & $\begin{array}{c}\text { Pembacaan } \\
\text { Sensor }\end{array}$ & $\begin{array}{c}\text { Kondisi } \\
\text { Kesehatan }\end{array}$ & Waktu \\
\hline \multirow{7}{*}{1.} & Usia & 60 & \multirow{7}{*}{ Sehat } & \multirow{7}{*}{$\begin{array}{c}\text { Senin, } \\
21-6- \\
2021\end{array}$} \\
\hline & Jenis Kelamin & Perempuan & & \\
\hline & Detak Jantung & 75.32 & & \\
\hline & Suhu Tubuh & 36.73 & & \\
\hline & TD Sistolik & 130.25 & & \\
\hline & TD Diastolik & 71.34 & & \\
\hline & Kadar Oksigen & 96.00 & & \\
\hline \multirow{7}{*}{2.} & Usia & 76 & \multirow{7}{*}{ Indikasi } & \multirow{7}{*}{$\begin{array}{c}\text { Senin, } \\
21-6- \\
2021 \\
12: 26\end{array}$} \\
\hline & Jenis Kelamin & Perempuan & & \\
\hline & Detak Jantung & 53.84 & & \\
\hline & Suhu Tubuh & 36.77 & & \\
\hline & TD Sistolik & 137.78 & & \\
\hline & TD Diastolik & 90.99 & & \\
\hline & Kadar Oksigen & 97.00 & & \\
\hline \multirow{7}{*}{3.} & Usia & 63 & \multirow{7}{*}{ Sehat } & \multirow{7}{*}{$\begin{array}{c}\text { Senin, } \\
21-6- \\
2021\end{array}$} \\
\hline & Jenis Kelamin & Perempuan & & \\
\hline & Detak Jantung & 66.10 & & \\
\hline & Suhu Tubuh & 36.69 & & \\
\hline & TD Sistolik & 121.05 & & \\
\hline & TD Diastolik & 75.97 & & \\
\hline & Kadar Oksigen & 95.00 & & \\
\hline
\end{tabular}

Tabel 8. Hasil Monitoring Kesehatan Lansia Sore

\begin{tabular}{|c|c|c|c|c|}
\hline No & $\begin{array}{c}\text { Paramater } \\
\text { Kesehatan } \\
\text { Tubuh }\end{array}$ & $\begin{array}{c}\text { Pembacaan } \\
\text { Sensor }\end{array}$ & $\begin{array}{c}\text { Kondisi } \\
\text { Kesehatan }\end{array}$ & Waktu \\
\hline \multirow{7}{*}{1.} & Usia & 60 & \multirow{7}{*}{ Sehat } & \multirow{7}{*}{$\begin{array}{l}\text { Senin, } \\
21-6- \\
2021\end{array}$} \\
\hline & Jenis Kelamin & Perempuan & & \\
\hline & Detak Jantung & 73.32 & & \\
\hline & Suhu Tubuh & 36.23 & & \\
\hline & TD Sistolik & 126.95 & & \\
\hline & TD Diastolik & 65.09 & & \\
\hline & Kadar Oksigen & 96.00 & & \\
\hline \multirow{7}{*}{2.} & Usia & 76 & \multirow{7}{*}{ Indikasi } & \multirow{7}{*}{$\begin{array}{c}\text { Senin, } \\
21-6- \\
2021\end{array}$} \\
\hline & Jenis Kelamin & Perempuan & & \\
\hline & Detak Jantung & 58.04 & & \\
\hline & Suhu Tubuh & 36.62 & & \\
\hline & TD Sistolik & 133.04 & & \\
\hline & TD Diastolik & 80.09 & & \\
\hline & Kadar Oksigen & 95.00 & & \\
\hline \multirow{7}{*}{3.} & Usia & 63 & \multirow{7}{*}{ Sehat } & \multirow{7}{*}{$\begin{array}{c}\text { Senin, } \\
21-6- \\
2021\end{array}$} \\
\hline & Jenis Kelamin & Perempuan & & \\
\hline & Detak Jantung & 68.20 & & \\
\hline & Suhu Tubuh & 36.40 & & \\
\hline & TD Sistolik & 121.05 & & \\
\hline & TD Diastolik & 76.50 & & \\
\hline & Kadar Oksigen & 95.00 & & \\
\hline
\end{tabular}

Pada saat melakukan proses monitoring kesehatan, semua hasil pembacaan sensor terbaca oleh alat 1 . Selanjutnya dikirim ke pangkalan data kemudian android akan menampilkan hasil dari pembacaan sensor tersebut. Ketiga tabel diatas yaitu 6, 7 dan juga 8 ialah hasil monitoring kesehatan lansia pada rentang waktu dari 09:10 sampai dengan 15:00 sore hari. Tabel 6 adalah hasil monitoring kesehatan lansia waktu pagi hari hasil pembacaan data pertama yaitu perempuan berumur 60 tahun didapatkan nilai detak jantung $74.32 \mathrm{bpm}$, suhu tubuh $36.53\left({ }^{\circ} \mathrm{C}\right)$, tekanan darah sistolik $128.25 \mathrm{mmHg}$, tekanan darah diastolik 70.79 dan kadar oksigen dalam darah bernilai $95.00 \%$ didapatkan kondisi kesehatan "Sehat". Tabel 7 adalah hasil monitoring kesehatan lansia pada waktu siang terlihat pada data pertama tekanan darah mengalami peningkatan namun masih dikatakan normal. Pada Tabel 8 adalah hasil monitoring kesehatan lansia pada waktu sore hari suhu tubuh mengalami penurunan yang sebelumnya pada pagi dan siang diatas 36.5 sampai 36.7, pada waktu sore hari suhu tubuh berkisar di rentang 36.2 sampai 36.6. Detak jantung pada waktu pagi, siang, dan sore tidak adanya perubahan yang terlalu signifikan, dan untuk kadar oksigen dalam darah pada siang hari mengalami penaikan.

\section{B. Hasil Pengujian Monitoring Kesehatan Tubuh pada Alat 2}

Lokasi pengujian pada alat 2 dilakukan pada masyarakat disekitar pada rentang usia dewasa. Berikut adalah hasil monitoring kesehatan dewasa saat pagi, siang, dan sore hari.

Tabel 9. Hasil Monitoring Kesehatan Dewasa Pagi

\begin{tabular}{|c|c|c|c|c|}
\hline No & $\begin{array}{c}\text { Paramater } \\
\text { Kesehatan } \\
\text { Tubuh }\end{array}$ & $\begin{array}{c}\text { Pembacaan } \\
\text { Sensor }\end{array}$ & $\begin{array}{c}\text { Kondisi } \\
\text { Kesehatan }\end{array}$ & Waktu \\
\hline \multirow{7}{*}{1.} & Usia & 30 & \multirow{7}{*}{ Sehat } & \multirow{7}{*}{$\begin{array}{c}\text { Selasa, } \\
22-6- \\
2021\end{array}$} \\
\hline & Jenis Kelamin & Laki -Laki & & \\
\hline & Detak Jantung & 74.32 & & \\
\hline & Suhu Tubuh & 36.53 & & \\
\hline & TD Sistolik & 128.25 & & \\
\hline & TD Diastolik & 70.79 & & \\
\hline & Kadar Oksigen & 95.00 & & \\
\hline \multirow{7}{*}{2.} & Usia & 33 & \multirow{7}{*}{ Sehat } & \multirow{3}{*}{$\begin{array}{l}\text { Selasa, } \\
22-6-\end{array}$} \\
\hline & Jenis Kelamin & Laki - Laki & & \\
\hline & Detak Jantung & 70.13 & & \\
\hline & Suhu Tubuh & 36.78 & & \multirow{4}{*}{$\begin{array}{c}2021 \\
09: 35\end{array}$} \\
\hline & TD Sistolik & 129.64 & & \\
\hline & TD Diastolik & 70.28 & & \\
\hline & Kadar Oksigen & 95.00 & & \\
\hline \multirow{7}{*}{3.} & Usia & 28 & \multirow{7}{*}{ Sehat } & \multirow{7}{*}{$\begin{array}{c}\text { Selasa, } \\
22-6- \\
2021\end{array}$} \\
\hline & Jenis Kelamin & Perempuan & & \\
\hline & Detak Jantung & 68.04 & & \\
\hline & Suhu Tubuh & 36.60 & & \\
\hline & TD Sistolik & 120.05 & & \\
\hline & TD Diastolik & 75.57 & & \\
\hline & Kadar Oksigen & 95.00 & & \\
\hline
\end{tabular}


Tabel 10. Hasil Monitoring Kesehatan Dewasa Siang

\begin{tabular}{|c|c|c|c|c|}
\hline No & $\begin{array}{c}\text { Paramater } \\
\text { Kesehatan Tubuh }\end{array}$ & $\begin{array}{c}\text { Pembacaan } \\
\text { Sensor }\end{array}$ & $\begin{array}{c}\text { Kondisi } \\
\text { Kesehatan }\end{array}$ & Waktu \\
\hline \multirow{7}{*}{1.} & Usia & 30 & \multirow{7}{*}{ Sehat } & \multirow{7}{*}{$\begin{array}{c}\text { Selasa, } \\
22-6- \\
2021\end{array}$} \\
\hline & Jenis Kelamin & Laki -Laki & & \\
\hline & Detak Jantung & 74.32 & & \\
\hline & Suhu Tubuh & 36.65 & & \\
\hline & TD Sistolik & 130.25 & & \\
\hline & TD Diastolik & 71.88 & & \\
\hline & Kadar Oksigen & 95.00 & & \\
\hline \multirow{7}{*}{2.} & Usia & 33 & \multirow{7}{*}{ Sehat } & \multirow{7}{*}{$\begin{array}{c}\text { Selasa, } \\
22-6- \\
2021\end{array}$} \\
\hline & Jenis Kelamin & Laki - Laki & & \\
\hline & Detak Jantung & 73.10 & & \\
\hline & Suhu Tubuh & 36.75 & & \\
\hline & TD Sistolik & 130.02 & & \\
\hline & TD Diastolik & 71.06 & & \\
\hline & Kadar Oksigen & 95.00 & & \\
\hline \multirow{7}{*}{3.} & Usia & 28 & \multirow{7}{*}{ Indikasi } & \multirow{7}{*}{$\begin{array}{c}\text { Selasa, } \\
22-6- \\
2021 \\
\\
12: 50\end{array}$} \\
\hline & Jenis Kelamin & Perempuan & & \\
\hline & Detak Jantung & 61.20 & & \\
\hline & Suhu Tubuh & 36.56 & & \\
\hline & TD Sistolik & 121.08 & & \\
\hline & TD Diastolik & 76.07 & & \\
\hline & Kadar Oksigen & 95.00 & & \\
\hline
\end{tabular}

Tabel 11. Hasil Monitoring Kesehatan Dewasa Sore

\begin{tabular}{|c|c|c|c|c|}
\hline No & $\begin{array}{c}\text { Paramater } \\
\text { Kesehatan } \\
\text { Tubuh }\end{array}$ & $\begin{array}{c}\text { Pembacaan } \\
\text { Sensor }\end{array}$ & $\begin{array}{c}\text { Kondisi } \\
\text { Kesehatan }\end{array}$ & Waktu \\
\hline \multirow{7}{*}{1.} & Usia & 30 & \multirow{7}{*}{ Sehat } & \multirow{7}{*}{$\begin{array}{c}\text { Selasa, } \\
22-6- \\
2021\end{array}$} \\
\hline & Jenis Kelamin & Laki -Laki & & \\
\hline & Detak Jantung & 74.50 & & \\
\hline & Suhu Tubuh & 36.60 & & \\
\hline & TD Sistolik & 129.05 & & \\
\hline & TD Diastolik & 71.09 & & \\
\hline & Kadar Oksigen & 95.00 & & \\
\hline \multirow{7}{*}{2.} & Usia & 33 & \multirow{7}{*}{ Sehat } & \multirow{7}{*}{$\begin{array}{c}\text { Selasa, } \\
22-6- \\
2021\end{array}$} \\
\hline & Jenis Kelamin & Laki - Laki & & \\
\hline & Detak Jantung & 72.60 & & \\
\hline & Suhu Tubuh & 36.70 & & \\
\hline & TD Sistolik & 128.84 & & \\
\hline & TD Diastolik & 69.08 & & \\
\hline & Kadar Oksigen & 95.00 & & \\
\hline \multirow{7}{*}{3.} & Usia & 28 & \multirow{7}{*}{ Indikasi } & \multirow{7}{*}{$\begin{array}{c}\text { Selasa, } \\
22-6- \\
2021 \\
15: 00\end{array}$} \\
\hline & Jenis Kelamin & Perempuan & & \\
\hline & Detak Jantung & 61.00 & & \\
\hline & Suhu Tubuh & 36.50 & & \\
\hline & TD Sistolik & 120.05 & & \\
\hline & TD Diastolik & 70.87 & & \\
\hline & Kadar Oksigen & 95.00 & & \\
\hline
\end{tabular}

Tiga tabel diatas yaitu Tabel 9, 10 dan 11 adalah beberapa hasil monitoring kesehatan untuk rentang dewasa menggunakan alat 2 pada waktu pagi, siang, dan sore. Tabel 9 monitoring dilakukan pada pagi hari, dari hasil pembacaan terlihat laki - laki berusia 30 tahun mempunyai kondisi kesehatan "Sehat" dengan detak jantung bernilai 74.32 , suhu tubuh 36.53 , tekanan darah sistolik bernilai 128.25 , tekanan darah diastolik bernilai 70.79 , dan kadar oksigen dalam darah yang dimilikinya $95.00 \%$. Terlihat perbedaan tekanan darah pada waktu pagi, siang dan sore yaitu nilai tekanan darah dari waktu pagi meningkat hingga siang hari, ketika waktu sore tekanan darah mulai menurun. Suhu tubuh untuk rentang usia dewasa pada waktu pagi, siang dan sore mengalami kenaikan dan juga penurunan yang tidak terlalu tinggi dan rendah. Untuk kadar oksigen dalam darah terlihat stabil tidak adanya peningkatan dan penurunan yang drastis, beda halnya dengan detak jantung untuk seorang perumpuan berusia 28 tahun pada pagi hari memiliki nilai detak jantung sebesar $68.04 \mathrm{bpm}$, pada waktu siang dan sore mengalami penurunan menjadi dibawah $62.00 \mathrm{bpm}$.

\section{Hasil Pengujian Monitoring Kesehatan Tubuh} pada Alat 3

Lokasi pengujian pada alat 3 dilakukan pada masyarakat disekitar pada rentang usia remaja Berikut adalah hasil monitoring kesehatan remaja saat pagi, siang, dan sore hari.

Tabel 12. Hasil Monitoring Kesehatan Remaja Pagi

\begin{tabular}{|c|c|c|c|c|}
\hline No & $\begin{array}{c}\text { Paramater } \\
\text { Kesehatan Tubuh }\end{array}$ & $\begin{array}{c}\text { Pembacaan } \\
\text { Sensor }\end{array}$ & $\begin{array}{c}\text { Kondisi } \\
\text { Kesehatan }\end{array}$ & Waktu \\
\hline \multirow{7}{*}{1.} & Usia & 14 & \multirow{7}{*}{ Sehat } & \multirow{7}{*}{$\begin{array}{c}\text { Rabu, } \\
23-6- \\
2021\end{array}$} \\
\hline & Jenis Kelamin & Perempuan & & \\
\hline & Detak Jantung & 74.32 & & \\
\hline & Suhu Tubuh & 36.53 & & \\
\hline & TD Sistolik & 126.25 & & \\
\hline & TD Diastolik & 70.79 & & \\
\hline & Kadar Oksigen & 96.00 & & \\
\hline \multirow{7}{*}{2.} & Usia & 16 & \multirow{7}{*}{ Sehat } & \multirow{7}{*}{$\begin{array}{c}\text { Selasa, } \\
23-6- \\
2021\end{array}$} \\
\hline & Jenis Kelamin & Laki - Laki & & \\
\hline & Detak Jantung & 77.67 & & \\
\hline & Suhu Tubuh & 36.46 & & \\
\hline & TD Sistolik & 119.54 & & \\
\hline & TD Diastolik & 76.19 & & \\
\hline & Kadar Oksigen & 95.00 & & \\
\hline \multirow{7}{*}{3.} & Usia & 18 & \multirow{7}{*}{ Sehat } & \multirow{7}{*}{$\begin{array}{c}\text { Selasa, } \\
23-6- \\
2021\end{array}$} \\
\hline & Jenis Kelamin & Laki - Laki & & \\
\hline & Detak Jantung & 69.00 & & \\
\hline & Suhu Tubuh & 36.60 & & \\
\hline & TD Sistolik & 120.00 & & \\
\hline & TD Diastolik & 75.56 & & \\
\hline & Kadar Oksigen & 95.00 & & \\
\hline
\end{tabular}

Tabel 13. Hasil Monitoring Kesehatan Remaja Siang

\begin{tabular}{|c|c|c|c|c|}
\hline No & $\begin{array}{c}\text { Paramater } \\
\text { Kesehatan Tubuh }\end{array}$ & $\begin{array}{c}\text { Pembacaan } \\
\text { Sensor }\end{array}$ & $\begin{array}{c}\text { Kondisi } \\
\text { Kesehatan }\end{array}$ & Waktu \\
\hline \multirow{7}{*}{1.} & Usia & 14 & \multirow{7}{*}{ Sehat } & \multirow{5}{*}{$\begin{array}{c}\text { Rabu, } \\
23-6- \\
2021\end{array}$} \\
\hline & Jenis Kelamin & Perempuan & & \\
\hline & Detak Jantung & 78.32 & & \\
\hline & Suhu Tubuh & 36.25 & & \\
\hline & TD Sistolik & 128.25 & & \\
\hline & TD Diastolik & 72.79 & & \multirow[t]{2}{*}{$12: 10$} \\
\hline & Kadar Oksigen & 97.00 & & \\
\hline \multirow{3}{*}{2.} & Usia & 16 & \multirow{3}{*}{ Sehat } & \multirow{3}{*}{$\begin{array}{c}\text { Rabu, } \\
23-6- \\
2021\end{array}$} \\
\hline & Jenis Kelamin & Laki -Laki & & \\
\hline & Detak Jantung & 78.34 & & \\
\hline
\end{tabular}




\begin{tabular}{|c|c|c|c|c|}
\hline & Suhu Tubuh & 36.89 & & \multirow{4}{*}{$12: 35$} \\
\hline & TD Sistolik & 119.54 & & \\
\hline & TD Diastolik & 76.19 & & \\
\hline & Kadar Oksigen & 96.00 & & \\
\hline \multirow{7}{*}{3.} & Usia & 18 & \multirow{7}{*}{ Indikasi } & \multirow{7}{*}{$\begin{array}{l}\text { Rabu, } \\
23-6- \\
2021\end{array}$} \\
\hline & Jenis Kelamin & Laki-Laki & & \\
\hline & Detak Jantung & 61.00 & & \\
\hline & Suhu Tubuh & 36.90 & & \\
\hline & TD Sistolik & 120.05 & & \\
\hline & TD Diastolik & 78.37 & & \\
\hline & Kadar Oksigen & 95.00 & & \\
\hline
\end{tabular}

Tabel 14. Hasil Monitoring Kesehatan Remaja Sore

\begin{tabular}{|c|c|c|c|c|}
\hline No & $\begin{array}{c}\text { Paramater } \\
\text { Kesehatan Tubuh }\end{array}$ & $\begin{array}{c}\text { Pembacaan } \\
\text { Sensor }\end{array}$ & $\begin{array}{c}\text { Kondisi } \\
\text { Kesehatan }\end{array}$ & Waktu \\
\hline \multirow{7}{*}{1.} & Usia & 14 & \multirow{7}{*}{ Sehat } & \multirow{7}{*}{$\begin{array}{c}\text { Rabu, } \\
23-6- \\
2021\end{array}$} \\
\hline & Jenis Kelamin & Perempuan & & \\
\hline & Detak Jantung & 84.32 & & \\
\hline & Suhu Tubuh & 36.41 & & \\
\hline & TD Sistolik & 125.23 & & \\
\hline & TD Diastolik & 72.79 & & \\
\hline & Kadar Oksigen & 95.00 & & \\
\hline \multirow{7}{*}{2.} & Usia & 16 & \multirow{7}{*}{ Sehat } & \multirow{7}{*}{$\begin{array}{c}\text { Rabu, } \\
23-6- \\
2021\end{array}$} \\
\hline & Jenis Kelamin & Laki - Laki & & \\
\hline & Detak Jantung & 79.67 & & \\
\hline & Suhu Tubuh & 36.56 & & \\
\hline & TD Sistolik & 118.49 & & \\
\hline & TD Diastolik & 78.19 & & \\
\hline & Kadar Oksigen & 95.00 & & \\
\hline \multirow{7}{*}{3.} & Usia & 18 & \multirow{7}{*}{ Sehat } & \multirow{7}{*}{$\begin{array}{c}\text { Rabu, } \\
23-6- \\
2021\end{array}$} \\
\hline & Jenis Kelamin & Perempuan & & \\
\hline & Detak Jantung & 73.55 & & \\
\hline & Suhu Tubuh & 36.50 & & \\
\hline & TD Sistolik & 119.67 & & \\
\hline & TD Diastolik & 75.57 & & \\
\hline & Kadar Oksigen & 95.00 & & \\
\hline
\end{tabular}

Pada hasil monitoring kesehatan remaja pada waktu pagi, siang,dan sore terlihat pada Tabel 12, 13, dan juga 14 kondisi kesehatan remaja hampir semuanya dalam kondisi sehat. Seperti yang terlihat dalam Tabel 12, seorang laki - laki berusia 16 tahun memiliki detak jantung 77.67, suhu tubuh 36.67, tekanan darah sistolik 119.54, tekanan darah diastolik 76.19, dan kadar oksigen dalam darah bernilai 95. Terlihat dari hasil monitoring tekanan darah pada remaja cenderung stabil tidak mengalami penurunan dan peningkatan yang cukup signifikan. Namun masih terlihat menjelang siang hari tekanan darah meningkat dan pada sore hari tekanan darah menurun. Suhu tubuh pada pagi, siang, dan sore selalu berubah - ubah, hal ini dapat dikarenakan karena faktor lingkungan. Detak jantung dan kadar oksigen dalam darah cenderung stabil tidak mengalami penurunan dan peningkatan secara drastis. Dari hasil monitoring dapat terlihat pada usia tua atau lansia cenderung memiliki kondisi kesehatan indikasi dikarenakan memang faktor usia yang dapat mempengaruhi hal itu. Pada hasil monitoring dewasa dominan memiliki kondisi kesehatan sehat, hanya beberapa yang mendapatkan kondisi kesehatan indikasi, dan yang terakhir hasil monitoring kesehatan remaja 90\% memiliki kondisi kesehatan sehat. Dengan ini terlihat bahwa usia sangat mempengaruhi faktor kesehatan. Terlihat dari hasil monitoring kesehatan untuk jenis kelamin perempuan dan laki - laki tidak terlihat perbedaan yang dominan. Namun suhu tubuh laki - laki cenderung lebih tinggi dari perempuan. Beda halnya dengan tekanan darah laki - laki memiliki nilai lebih rendah dibandingkan dengan perempuan.

Dari hasil monitoring kesehatan tubuh yang dilakukan untuk menghitung tingkat akurasi metode fuzzy mamdani dilakukan perhitungan seperti berikut. Tabel berikut ini juga memperlihatkan perbandingan hasil kondisi kesehatan mengggunakan metode fuzzy mamdani dengan data sebenarnya.

Tabel 15. Tabel Perbandingan dengan Data Sebenarnya

\begin{tabular}{|c|c|c|c|c|c|}
\hline No & $\begin{array}{c}\text { Rentang } \\
\text { Usia }\end{array}$ & Waktu & $\begin{array}{c}\text { Kondisi } \\
\text { Kesehatan } \\
\text { Fuzzy } \\
\text { Mandani } \\
\end{array}$ & $\begin{array}{c}\text { Kondisi } \\
\text { Kesehatan } \\
\text { Data } \\
\text { Sebenarnya }\end{array}$ & Hasil \\
\hline 1. & \multirow{9}{*}{ Lansia } & \multirow{3}{*}{ Pagi } & Sehat & Sehat & Sesuai \\
\hline 2. & & & Indikasi & Indikasi & Sesuai \\
\hline 3. & & & Indikasi & Sehat & $\begin{array}{l}\text { Tidak } \\
\text { Sesuai }\end{array}$ \\
\hline 4. & & \multirow{3}{*}{ Siang } & Sehat & Sehat & Sesuai \\
\hline 5. & & & Indikasi & Indikasi & Sesuai \\
\hline 6. & & & Sehat & Sehat & Sesuai \\
\hline 7. & & \multirow{3}{*}{ Sore } & Sehat & Sehat & Sesuai \\
\hline 8. & & & Indikasi & Indikasi & Sesuai \\
\hline 9. & & & Sehat & Sehat & Sesuai \\
\hline 10. & \multirow{9}{*}{ Dewasa } & \multirow{3}{*}{ Pagi } & Sehat & Sehat & Sesuai \\
\hline 11. & & & Sehat & Sehat & Sesuai \\
\hline 12. & & & Sehat & Sehat & Sesuai \\
\hline 13. & & \multirow{3}{*}{ Siang } & Sehat & Sehat & Sesuai \\
\hline 14. & & & Sehat & Sehat & Sesuai \\
\hline 15. & & & Indikasi & Sehat & $\begin{array}{l}\text { Tidak } \\
\text { Sesuai }\end{array}$ \\
\hline 16. & & \multirow{3}{*}{ Sore } & Sehat & Sehat & Sesuai \\
\hline 17. & & & Sehat & Sehat & Sesuai \\
\hline 18. & & & Indikasi & Sehat & $\begin{array}{l}\text { Tidak } \\
\text { Sesuai } \\
\end{array}$ \\
\hline 19. & \multirow{9}{*}{ Remaja } & \multirow{3}{*}{ Pagi } & Sehat & Sehat & Sesuai \\
\hline 20. & & & Sehat & Sehat & Sesuai \\
\hline 21. & & & Sehat & Sehat & Sesuai \\
\hline 22. & & \multirow{3}{*}{ Siang } & Sehat & Sehat & Sesuai \\
\hline 23. & & & Sehat & Sehat & Sesuai \\
\hline 24. & & & Indikasi & Sehat & $\begin{array}{c}\text { Tidak } \\
\text { Sesuai }\end{array}$ \\
\hline 25. & & \multirow{3}{*}{ Sore } & Sehat & Sehat & Sesuai \\
\hline 26. & & & Sehat & Sehat & Sesuai \\
\hline 27. & & & Sehat & Sehat & Sesuai \\
\hline
\end{tabular}

Akurasi $(\%)=$ Jumlah data yang sesuai $\times 100 \%$ Jumlah keseluruhan data

$=\frac{23}{27} \times 100 \%$

$=85,18 \%$ 
Dari perhitungan diatas dapat disimpulkan bahwa tingkat akurasi metode fuzzy mamdani pada penentuan kondisi kesehatan tubuh sebesar $85,18 \%$.

\section{KESIMPULAN}

Dari hasil penelitian yang telah dilakukan, maka dapat disimpulkan bahwa metode fuzzy mamdani berhasil menentukan kondisi kesehatan tubuh dengan performansi akurasi yang cukup tinggi. Hal ini dikarenakan akurasi metode fuzzy mamdani mencapai nilai akurasi diatas 80\%. Dari penelitian yang telah dilakukan, apabila menggunakan algoritma fuzzy mamdani dengan banyak variabel, akan menyebabkan banyaknya aturan fuzzy yang dibuat. Dari pengujian ini digunakan tujuh variabel, alhasil aturan yang digunakan menjadi 1728. Hal ini mungkin dapat dimemicu kekeliruan. Berdasarkan kesimpulan pada penelitian ini, maka disarankan untuk menentukan kondisi kesehatan tubuh menggunakan metode yang lain, agar kondisi kesehatan yang didapatkan lebih akurat lagi.

\section{DAFTAR PUSTAKA}

[1] R. S. Kusuma, M. Pamungkasty, F. S. Akbaruddin, and U. Fadlilah, "PROTOTIPE ALAT MONITORING KESEHATAN JANTUNG BERBASIS IoT," Emit. J. Tek. Elektro, vol. 18, no. 2, pp. 18-22, 2018, doi: 10.23917/emitor.v18i2.6353.

[2] P. Studi et al., "RANCANG BANGUN MONITORING DETAK JANTUNG ( HEART RATE ) SEBAGAI INDIKATOR KESEHATAN BERBASIS INTERNET OF THINGS ( IOT ) Design and Build Monitoring Heart Rate As An Indicator Of Health Based."

[3] N. Ahmed, M. Ajmal, M. Hai, A. Khuzema, and M. Tariq, "Real Time Monitoring of Human Body Vital Signs using Bluetooth and WLAN," Int. J. Adv. Comput. Sci. Appl., vol. 7, no. 10, pp. 210-216, 2016, doi: 10.14569/ijacsa.2016.071028.

[4] P. . Puspitaningayu, A. . Widodo, and E. . Yundra, "Wireless Body Area Networks dan Pengaruhnya dalam Perkembangan Teknologi m-Health," Ina. Indones. J. Electr. Eletronics Eng., vol. 1, no. 1, p. 24, 2018, doi: 10.26740/inajeee.v1n1.p24-30.

[5] R. Srinivasan and E. Kannan, "A review on energy efficient routing protocols in wireless sensor networks," Int. J. Appl. Eng. Res., vol. 10, no. 11, pp. 27701-27715, 2015, doi: 10.26634/jwcn.4.4.5912.

[6] M. U. H. Al Rasyid, B. H. Lee, and A. Sudarsono, "Wireless body area network for monitoring body temperature, heart beat and oxygen in blood," 2015 Int. Semin. Intell. Technol. Its Appl. ISITIA 2015 - Proceeding, pp. 95-98, 2015, doi: 10.1109/ISITIA.2015.7219960.

[7] R. Mohammed, D. Omer, and N. K. Al-salihi, "Monitoring ( SWSHM )," 2017.

[8] I. Prayogo, R. Alfita, and K. A. Wibisono, "Sistem Monitoring Denyut Jantung Dan Suhu Tubuh Sebagai Indikator Level Kesehatan Pasien Berbasis Iot (Internet Of Thing) Dengan Metode Fuzzy Logic Menggunakan Android," J. Tek. Elektro dan Komput. TRIAC, vol. 4, no. 2, 2017, doi: 10.21107/triac.v4i2.3257.

[9] B. Rifai, "Algoritma Neural Network Untuk Prediksi," Techno Nusa Mandiri, vol. IX, no. 1, pp. 1-9, 2013.

[10] I. Santosa, H. Rosiyah, and E. Rahmanita, "Implementasi Algoritma Decision Tree C . 45 Untuk Diagnosa Penyakit Tubercolusis ( Tb )," J. Ilm. NERO, vol. 3, no. 3, pp. 169-176, 2018.

[11] N. Febriany, "Bab iii metode fuzzy mamdani," pp. 29-49, 2016.

[12] A. Citra Mutia, A. F. Sundoro, A. Yajiddin, M. Khoirullah, and D. Q. Aini, "Review Penerapan Fuzzy Logic Sugeno Dan Mamdani Pada Sistem Pendukung Keputusan Prakiraan Cuaca Di Indonesia," Semin. Nas. Sist. Inf. Indones., no. November, 2017, [Online]. Available:

http://is.its.ac.id/pubs/oajis/index.php/home/d etail/1753/REVIEW-PENERAPAN-FUZZYLOGIC-SUGENO-DAN-MAMDANIPADA-SISTEM-PENDUKUNGKEPUTUSAN-PRAKIRAAN-CUACA-DIINDONESIA.

[13] B. Setia, "Penerapan Logika Fuzzy pada Sistem Cerdas," J. Sist. Cerdas, vol. 2, no. 1, pp. 61-66, 2019, doi: 10.37396/jsc.v2i1.18.

[14] N. Febriany, F. Agustina, and R. Marwati, "Aplikasi Metode Fuzzy Mamdani Dalam Penentuan Status Gizi Dan Menggunakan Software Matlab," J. EurekaMatika, vol. 5, no. 1, pp. 84-96, 2017.

[15] S. Widodo, M. M. Amin, A. Supani, and A. S. Handayani, "Prototype Design of CO2, CH4 and SO2 Toxic Gas Detectors in the Room Using Microcontroller-Based Fuzzy Logic," J. Phys. Conf. Ser., vol. 1500, no. 1, pp. 0-13, 2020, doi: 10.1088/1742-6596/1500/1/012107.

[16] Nasri, "Kecerdasan buatan ( Artificial Intelligence )," Artif. Intell., vol. 1, no. 2, pp. 1-10, 2014.

[17] N. Khairina, "Analisis Fungsi Keanggotaan Fuzzy Tsukamoto Dalam Menentukan Status Kesehatan Tubuh Seseorang," SinkrOn, vol. 1, no. 1, p. 19, 2017, doi: 10.33395/sinkron.v1i1.5.

[18] S. Nurmuslimah, "Aplikasi Fuzzy Logic Mamdani untuk Perkembangan Pertumbuhan 
Anak Berdasarkan BGM-KMS," Integer, vol. 1, no. 1, pp. 59-66, 2016.

[19] M. S. Asih, "Sistem Pendukung Keputusan Fuzzy Mamdani pada Alat Penyiraman Tanaman Otomatis," J. Sist. Inf., vol. 5341, no. April, pp. 41-52, 2018, [Online]. Available: http://jurnal.uinsu.ac.id/index.php/query/articl e/view/1566/1271.

[20] Hidayah, Nuril, Martinus Mujur Rose, and Nasron Nasron. "Rancang Bangun Alat Pendeteksi Tingkat Stress Pada Manusia Berbasis Arduino Uno." PROtek: Jurnal Ilmiah Teknik Elektro 8.1 (2021): 31-39. 